\title{
Analisis Semiotik “Hujan Bulan Juni” vs "Percakapan Senja”
}

\author{
Sifa \\ Balai Diklat Keagamaan Denpasar
}

\begin{tabular}{|c|c|}
\hline & ABSTRAK \\
\hline $\begin{array}{l}\text { Keywords: } \\
\text { Semiotic; } \\
\text { Poem; } \\
\text { Comparison }\end{array}$ & $\begin{array}{l}\text { Abstract: This study aims to compare semiotically between Sapardi Joko Damono's } \\
\text { "Rain of June" poem with "Dusk Conversation" Gde Artawan. In semiotic physics, the } \\
\text { lyrics of the poem Gde Artawan have an equivalent element in the choice of words, } \\
\text { immersing the word full of meaning as well as Sapardi Joko Damono's poem. } \\
\text { Although this poem is born at the same time, there are inner nuances that can be } \\
\text { juxtaposed. The method applied in this study is semiotic descriptive analysis as an } \\
\text { analysis knife. There is a deep inner struggle in "June Rain" versus "Dusk } \\
\text { Conversation". In "June Rain" ended with a "happy ending" while in "Twilight } \\
\text { Conversation" ended with a sad ending "the poem" Rain of June "ended in the } \\
\text { sweetness of a long wait. He gets someone who is very much awaited, sincerely in } \\
\text { love. He let unspoken everything he felt while waiting. While the poem "Twilight } \\
\text { Conversation" describes the end of a togetherness that reaps a deadlock that is } \\
\text { motivated by a very strong difference and the lack of a strong will to cross themselves } \\
\text { into a strong bond. In the end, let each other go according to their path. }\end{array}$ \\
\hline
\end{tabular}

\section{Kata kunci:}

Semiotik;

Puisi;

Perbandingan

\author{
Alamat Korespondensi: \\ E-mail: sifa-agus@yahoo.co.id

\begin{abstract}
Abstrak: Penelitian ini bertujuan untuk membandingkan secara semiotik antara puisi "Hujan Bulan Juni" Sapardi Joko Damono dengan "Percakapan Senja" Gde Artawan. Secara semiotis fisis, lirik puisi Gde Artawan memiliki unsur kesepadanan dalam pilihan kata, membenamkan kata sarat makna sebagaimana halnya puisi Sapardi Joko Damono. Meski puisi ini lahir dalam waktu yang tidak bersamaan, namun ada nuansa batin yang bisa disandingkan. Metode yang diterapkan dalam penelitian ini adalah analisis deskriptif dengan semiotik sebagai pisau analisis. Ada pergumulan batin yang mendalam dalam "Hujan Bulan Juni" versus "Percakapan Senja". Pada "Hujan Bulan Juni" diakhiri dengan "happy ending" sedang dalam "Percakapan Senja" berakhir dengan sad ending"puisi "Hujan Bulan Juni" berujung manisnya sebuah penantian panjang. Ia mendapatkan seseorang yang sangat dinantinya, dengan penuh tulus kasih. Ia membiarkan tak terucapkan segala apa yang ia rasa selama menanti. Sedangkan puisi "Percakapan Senja" menggambarkan tentang akhir sebuah kebersamaan yang menuai titik kebuntuan yang dilatarbelakangi oleh perbedaan yang sangat kuat dan ketiadaan kemauan yang kuat pula untuk saling melebarkan diri menjadi sebuah ikatan yang kuat. Pada akhirnya saling membiarkan masing-masing berjalan sesuai dengan jalurnya.
\end{abstract}

\section{Pendahuluan}

Puisi merupakan bentuk karya sastra yang paling kuno jika dibandingkan dengan bentuk-bentuk karya sastra yang lain. Sejak kelahirannya, puisi sudah menunjukkan ciri-ciri yang khas. Kata-katanya dipilih dengan cermat dan teliti agar memiliki kekuatan.

Semiotika sebagai salah satu kajian bahasa yang hidup di dalam masyarakat dan selalu melakukan interaksi dengan masyarakat lainnya tentu membutuhkan suatu alat komunikasi agar bisa saling memahami tentang suatu hal. Apa yang perlu dipahami? Banyak hal, salah satunya adalah tanda. Supaya tanda itu bisa dipahami secara benar dan sama mem-butuhkan konsep yang sama supaya tidak terjadi salah pengertian atau misunderstanding.

Namun pada kenyataannya tanda itu tidak selamanya bisa dipahami secara benar dan sama di antara masyarakat. Setiap orang memiliki interpretasi makna tersendiri dan tentu saja dengan berbagai alasan yang melatarbelakanginya. 
Puisi sebagai bagian dalam karya sastra pada dasarnya merupakan sarana ekspresi seseorang untuk menyamaikan perasaannya, imajinasinya, ataupun gagasannya. Dengan bahasa sebagai media sebuah puisi penyair menyajikan puisi dengan bahasa-bahasa yang telah dipilihnya. Bahasa pada dasarnya juga merupakan sebuah tanda yang memiliki arti. Seperti yang dikatakan oleh Pradopo (2010:121) kata-kata (bahasa) sebelum dipergunakan dalam karya sastra sudah merupakan lambang yang mempunyai arti yang ditentukan oleh perjanjian masyarakat(bahasa) atau ditentukan oleh konvensi masyarakat. Lambang-lambang atau kebahasaan itu berupa satuan-satuan bunyi yang mempunyai arti oleh konvensi masyarakat.

Untuk menciptakan puisi yang indah dan menarik perhatian pembacanya penyair selalu memilih kata-kata yang akan digunakan dalam puisinya. Yang menimbulkan arti lain di luar arti dari kata tersebut. Karangan atau tulisan yang indah itu dapat berasal dari pengalaman penyair ataupun dari penggambaran sesuatu.

Analisis semiotik adalah sebuah kajian dalam karya sastra yang mengkaji tentang unsur-unsur tanda dalam karya sastra tersebut. Analisis semiotik memandang bahwa sebuah karya sastra adalah kumpulan tanda-tanda yang dapat dinterpretasikan sesuai dengan konteksnya.

Membaca puisi- puisi Sapardi Djoko Damono dengan ciri khas penuturan yang prosais, dan membaca puisi - puisi Gde Artawan yang memiliki gaya penuturan mirip dengan puisi - puisi Sapardi, penulis tertarik untuk membandingkan salah satu puisi karya kedua penyair tersebut.

"Hujan Bulan Juni" adalah judul buku kumpulan puisi Sapardi Djoko Damono. Dan salah satu puisi di dalamnya berjudul "Hujan bulan Juni". Rupanya penyair memiliki kesan tersendiri terhadap nuansa puisi tersebut. Sama halnya Gde Artawan, judul buku kumpulan puisi Gde Artawan yakni: "Tubuhku Luka Pesisir Tubuhmu Luka Pegunungan" diambil dari salah satu puisinya yang berjudul "Percakapan Senja". Sepertinya sang penyair menyimpan kesan yang kuat terhadap puisi dimaksud. Karena itu penulis tertarik untuk mengkaji dua puisi tersebut secara lebih mendalam.

Mencermati puisi - puisi kedua penyair yang sarat simbol, maka penulis mencoba menganalisis dengan pisau analisis struktural- semiotik. Adapun puisi yang penulis pilih untuk disandingkan karena ada kedekatan suasana batin adalah "Hujan Bulan Juni" karya Sapardi Djoko Damono dan puisi "Percakapan Senja" karya Gde Artawan. Kedua puisi di atas memiliki kemiripan, terutama jika dilihat dari aspek fisik atau struktur lahir. Keduanya merupakan dialog imajiner. Komunikasi antara tokoh "aku" tokoh dengan "seseorang" terlihat dalam kedua puisi tersebut. Meski makna batin dari kedua puisi tersebut tidaklah bisa dikatakan sama. Analisis dalam BAB II akan mengupas anasir- anasir dalam kedua puisi dimaksud dengan menerapkan teori struktural- semiotik.

\section{Metode}

Data-data penelitian ini akan dianalisis menggunakan metode Analisis Wacana Kritis (Critical Discourse Analysis,CDA). Fairclough memahami CDA terkait dengan dua asumsi penggunaan bahasa: bahwa bahasa itu menyusun dan tersusun secara sosial. Ia mendasarkan gagasan ini pada teori linguistik multifungsional yang diwujudkan dalam 'lingusitik fungsional-sistemik' yang dikemukakan oleh Halliday; setiap teks memiliki fungsi 'ideasional' melalui representasi atas pengalaman dan representasi atas dunia ini. Melalui gagasan multifungsional bahasa dalam teks, Fairclough mengoperasionalkan asumsi teoritis bahwa teks dan wacana itu tersusun secara sosial. Penggunaan bahasa selalu tersusun atas; identitas sosial, relasi sosial, sistem pengetetahuan dan keyakinan.

Fairclough menandakan tiga dimensi pada setiap peristiwa diskursif yakni teks, praktik diskursif (mencakup produksi dan interpretasi teks), dan praktik sosial. Pertama, textual level, dilakukan analisis bentuk dan isi. Menurutnya, isi dan bentuk tidak dapat dipisahkan. Isi diwujudkan oleh bentuk tertentu; isi yang berbeda juga menyiratkan bentuk yang berbeda dan demikian sebaliknya. Yang dimaksud analisis linguistik suatu teks, menurut Fairclough adalah analisis fonologi, tata bahasa, kosakata, dan semantik. Kedua, level of discursive practice adalah hubungan antara teks dan praktik sosial. Praktik diskursif berkaitan dengan aspek sosio-kognitif produksi dan intepretasi teks. Di satu sisi, aspek tersebut dibentuk oleh praktik sosial dan membantu dalam pembentukannya, di sisi lain erat kaitannya dengan tataran tekstual. Oleh sebab itu, analisis praktik diskursif tidak hanya mencakup penjelasan yang tepat tentang cara partisipan menginterpretasikan dan menghasilkan teks dalam suatu interaksi, namun juga hubungan peristiwa-peristiwa diskursif dengan tatanan wacana, yang merupakan masalah interdiskursivitas. Ketiga, level of social practice, berhubungan dengan berbagai tataran organisasi sosial yang berbeda-beda: situasi, konteks institusional, konteks sosial atau kelompok yang lebih luas. Permasalahan kekuasaan menjadi tema pokok; kekuasaan dan ideologi bisa memberikan pengaruh terhadap masing-masing tataran kontekstual.

Selanjutnya Fairclough dan Wodak berpendapat bahwa analisis wacana kritis melihat wacana pemakaian bahasa dalam tuturan dan tulisan sebagai bentuk praktek social. Menggambarkan wacana 
sebagai praktik social menyebabkan sebuah hubungan dialektis di antara peristiwa diskursif tertentu dengan situasi, institusi, dan struktur sosial yang membentuknya. Praktik wacana bisa jadi menampilkan efek ideologi: ia dapat memproduksi dan mereproduksi hubungan kekuasaan yang tidak imbang antara kelas sosial, laki-laki dan wanita, kelompok mayoritas dan minoritas melalui mana perbedaan itu direpresentasikan dalam posisi social yang ditampilkan. Melalui wacana, sebagai contoh, keadaan yang rasis, seksis, atau ketimpangan dari kehidupan sosial dipandang sebagai sesuatu yang common sense, suatu kewajaran? alamiah, dan memang seperti itu kenyataannya. Analisis wacana kritis melihat bahasa sebagai faktor penting, yakni bagaimana bahasa digunakan untuk melihat ketimpangan kekuasaan dalam masyarakat terjadi. Analisis wacana kritis menyelidiki bagaimana melalui bahasa kelompok sosial yang ada saling bertarung dan mengajukan versinya masing-masing. Untuk itu, iklan-iklan rokok yang juga memiliki fungsi ideasional akan di analisis dengan menggunakan tiga pendekatan CDA dari Norman Fairclough. Dengan harapan dapat mengurai kompleksitas maskulin dalam iklan-iklan tersebut, sekaligus juga menemukan ideologi yang terkandung di dalamnya.

\section{Hasil dan Pembahasan}

Sekilas tentang Semiotik

Semiotik berasal dari bahasa Yunani, yaitu semeion yang berarti tanda. Tokoh yang dianggap pendiri semiotik adalah dua orang yang hidup sezaman, yang bekerja dalam bidang yang terpisah dan dalam lapangan yang tidak sama (tidak saling mempengaruhi), yang seorang ahli linguistik yaitu Ferdinand de Saussure (1857-1913) dan seorang ahli filsafat yaiutu Charles Sander Peirce (1839-1914). Saussure menyebut ilmu semiotik dengan nama semiologi, sedangkan Pierce menyebutnya semiotik (semiotics). Kemudian hal itu sering dipergunakan berganti-ganti dengan pengertian yang sama. Di Perancis dipergunakan nama semiologi untuk ilmu itu, sedang di Amerika lebih banyak dipakai nama semiotik (Pradopo, 2005:119).

Semiotik merupakan ilmu yang mempelajari sistem tanda-tanda. Dalam pengertian tanda ada dua prinsip, yaitu penanda (signifier) atau yang menandai, yang merupakan bentuk tanda, dan petanda (signified) atau yang ditandai, yang merupakan arti tanda. Berdasarkan hubungan antara penanda dan petanda, ada tiga jenis tanda yang pokok, yaitu ikon, indeks, dan simbol.

Ikon

Ikon adalah tanda hubungan antara penanda dan petandanya bersifat persamaan bentuk alamiah, misalnya potret orang menandai orang yang dipotret (berarti orang yang dipotret), gambar kuda itu menandai gambar kuda yang nyata.

Indeks

Indeks adalah tanda yang menunjukan adanya hubungan alamiah antara tanda dan petanda yang bersifat kausal atau hubungan sebab-akibat. Misalnya asap itu menandai api, suara menandai orang atau sesuatu yang mengeluarkan suara. Awan hitam pekat menandai akan turun hujan.

Simbol

Simbol itu tanda yang tidak menunjukkan hubungan alamiah antara penanda dan petandanya. Hubungan antaranya bersifat arbitrer atau semau-maunya, hubungannya berdasarkan konvensi (perjanjian) masyarakat. Sebuah sistem tanda yang utama yang menggunakan lambang adalah bahasa. Arti simnol ditentukan oleh masyarakat. Misalnya kata ibu berarti "orang yang melahirkan kita" itu terjadi atas konvensi atau perjanjian masyarakat bahasa Indonesia, masyarakar bahasa Inggris menyebutnya mother, Perancis: Ia mere. (Pradopo, 2010:121-122). Bendera warna hitam yang dipasang di depan rumah, menandai ada kedukaan yakni anggota keluarga yang meninggal dunia.

Semiotik merupakan lanjutan dari penelitian strukturalisme. Hubungan antara semiotik dan strukturalisme adalah sebagai berikut. Keterangan ini akan menjelaskan bagaimana sebenarnya hubungan antara semiotik dan strukturalisme.

(a) Semiotik digunakan untuk memberikan makna kepada tanda-tanda sesudah suatu penelitian struktural.

(b) Semiotik hanya dapat dilaksanakan melalui penelitian strukturalisme yang memungkinkan kita menemui tanda-tanda yang dapat memberi makna (Junus, 1988: 98).

Lebih lanjut Junus (1988: 98) menjelaskan bahwa pada (a) semiotik merupakan lanjutan dari strukturalisme. Pada (b) semiotik memerlukan untuk memungkinkan ia bekerja. Pada (a), semiotik seakan apendix 'ekor', kepada strukturalisme. Tapi tidak demikian halnya pada (b). Untuk menemukan tanda, sesuai dengan pengertian sebagai ilmu mengenai tanda. Semiotik tidak dapat memisahkan diri dari 
strukturalisme, ia memerlukan strukturalisme . dan sekaligus, semiotik juga menolong memahami suatu teks secara strukturalisme."

2.1 Tahapan Kajian Semiotik

Kajian semiotik melalui tahap-tahap diantaranya: 1) pembacaan heuristik yaitu pembacaan yang didasarkan pada konvensi bahasa yang bersifat mimetik atau tiruan alam yang membangun arti yang berserakan. Kajian ini didasarkan pada pemahaman yang lugas berdasarkan denotatif. 2) Selanjutnya, yaitu tahap pembacaan hermeneutik yaitu pembacaan yang bermuara pada ditemukannya satuan makna puisi secara utuh.

Michael Riffaterre dalam bukunya yang berjudul Semiotics of Poetry, mengemukakan bahwa ada empat hal yang harus diperhatikan dalam memahami dan memaknai sebuah puisi. Keempat hal tersebut adalah: (1) puisi adalah ekspresi tidak langsung, menyatakan suatu hal dengan arti yang lain, (2) pembacaan heuristik dan hermeneutik (retroaktif), (3) matriks, model, dan varian, dan (4) hipogram (Riffatere dalam Salam, 2009:3).

(1) Ketidaklangsungan Ekspresi dalam Puisi

Ciri penting puisi menurut Michael Riffaterre adalah puisi mengekspresikan konsep-konsep dan benda-benda secara tidak langsung. Sederhananya, puisi mengatakan satu hal dengan maksud hal lain. Hal inilah yang membedakan puisi dari bahasa pada umumnya. Puisi mempunyai cara khusus dalam membawakan maknanya (Faruk, 2012:141). Bahasa puisi bersifat semiotik sedangkan bahasa sehari-hari bersifat mimetik.

Ketidaklangsungan ekspresi puisi terjadi karena adanya pergeseran makna (displacing), perusakan makna (distorsing), dan penciptaan makna (creating) (Riffaterre dalam Faruk, 2012:141).

(a) Pergeseran Makna (Displacing of Meaning)

Pergeseran makna terjadi apabila suatu tanda mengalami perubahan dari satu arti ke arti yang lain, ketika suatu kata mewakili kata yang lain. Umumnya, penyebab terjadinya pergeseran makna adalah penggunaan bahasa kiasan, seperti metafora dan metonimi.

(b) Perusakan atau Penyimpangan Makna (Distorsing of Meaning)

Perusakan atau penyimpangan makna terjadi karena ambiguitas, kontradiksi, dan non-sense. Ambiguitas dapat terjadi pada kata, frasa, kalimat, maupun wacana yang disebabkan oleh munculnya penafsiran yang berbeda-beda menurut konteksnya. Kontradiksi muncul karena adanya penggunaan ironi, paradoks, dan antitesis. Non-sense adalah kata-kata yang tidak mempunyai arti (sesuai kamus) tetapi mempunyai makna "gaib" sesuai dengan konteks (Salam, 2009:4).

(c) Penciptaan Makna (Creating or Meaning)

Penciptaan makna berupa pemaknaan terhadap segala sesuatu yang dalam bahasa umum dianggap tidak bermakna, misalnya "simetri, rima, atau ekuivalensi semantik antara homolog-homolog dalam suatu stanza" (Riffaterre dalam faruk, 2012:141). Penciptaan arti terjadi karena pengorganisasian ruang teks, di antaranya: enjambemen, tipografi, dan homolog.

Enjambemen adalah peloncatan baris dalam sajak yang menyebabkan terjadinya peralihan perhatian pada kata akhir atau kata yang "diloncatkan" ke baris berikutnya. Pelocatan itu menimbulkan intensitas arti atau makna liris.

Tipografi adalah tata huruf. Tata huruf dalam teks biasa tidak mengandung arti tetapi dalam sajak akan menimbulkan arti. Sedangkan homolog adalah persejajaran bentuk atau baris. Bentuk yang sejajar itu akan menimbulkan makna yang sama (Salam, 2009:5).

Di antara ketiga ketidaklangsungan tersebut, ada satu faktor yang senantiasa ada, yaitu semuanya tidak dapat begitu saja dianggap sebagai representasi realitas. Representasi realitas hanya dapat diubah secara jelas dan tegas dalam suatu cara yang bertentangan dengan kemungkinan atau konteks yang diharapkan pembaca atau bisa dibelokkan tata bahasa atau leksikon yang menyimpang, yang disebut ketidakgramatikalan (ungrammaticality).

Dalam ruang lingkup sempit, ketidakgramatikalan berkaitan dengan bahasa yang dipakai di dalam karya sastra, misalnya pemakaian majas. Sebaliknya, dalam ruang lingkup luas, ketidakgramatikalan berkaitan dengan segala sesuatu yang "aneh" yang terdapat di dalam karya sastra, misalnya struktur naratif yang tidak kronologis.

(2). Pembacaan Heuristik dan Hermeneutik

Menifestasi semiotik adalah segala sesuatu yang berhubungan dengan tanda-tanda dari tingkat mimetik ke tingkat pemaknaan yang lebih tinggi. Proses semiotik pada dasarnya terjadi di dalam pikiran pembaca sebagai hasil dari pembacaan tahap kedua. Sebelum mencapai tahap pemaknaan, pembaca harus menghadapi rintangan pada tataran mimetik. Proses dekoding karya sastra diawali dengan pembacaan tahap pertama yang dilakukan dari awal hingga akhir teks. Pembacaan tahap pertama ini disebut sebagai pembacaan heuristik sedangkan pembacaan tahap kedua disebut sebagai pembacaan hermeneutik. 
Pembacaan heuristik adalah pembacaan sajak sesuai dengan tata bahasa normatif, morfologi, sintaksis, dan semantik. Pembacaan heuristik ini menghasilkan arti secara keseluruhan menurut tata bahasa normatif dengan sistem semiotik tingkat pertama.

Setelah melalui pembacaan tahap pertama, pembaca sampai pada pembacaan tahap kedua, yang disebut sebagai pembacaan retroaktif atau pembacaan hermeneutik. Pada tahap ini terjadi proses interpretasi tahap kedua, interpretasi yang sesungguhnya. Pembaca berusaha melihat kembali dan melakukan perbandingan berkaitan dengan yang telah dibaca pada proses pembacaan tahap pertama. Pembaca berada di dalam sebuah efek dekoding. Artinya pembaca mulai dapat memahami bahwa segala sesuatu yang pada awalnya, pada pembacaan tahap pertama, terlihat sebagai ketidakgramatikalan, ternyata merupakan fakta-fakta yang berhubungan.

Berkaitan dengan pembacaan heuristik dan hermeneutik, perlu dibedakan pengertian makna dan arti. Riffaterre dalam Faruk (2012:141) membedakan konsep makna dan arti. Makna yang terbangun dari hubungan kesamaan dengan realitas, yang membuatnya menjadi heterogen, yakni makna linguistik yang bersifat referensial dari karya disebut meaning, yang dapat diterjemahkan sebagai "makna", sedangkan makna yang terbangun atas dasar prinsip kesatuan formal dan semantik dari puisi, makna yang meliputi segala bentuk ketidaklangsungan, disebut sebagai significance yang dapat diterjemahkan sebagai "arti" (Faruk, 2012:142).

Dengan demikian, dapat dipahami bahwa "makna" (meaning) adalah semua informasi dalam tataran mimetik yang disajikan teks kepada pembaca, sedangkan "arti" (significance) adalah kesatuan antara aspek bentuk dan semantik. Secara sederhana, dapat dinyatakan bahwa makna sepenuhnya bersifat referensial sesuai dengan bahasa dan bersifat tekstual, sedangkan arti bisa saja "keluar" dari referensi kebahasaan dan mengacu kepada hal-hal di luar teks. Pada tataran pembacaan heuristik pembaca hanya mendapatkan "makna" sebuah teks, sedangkan "arti" diperoleh ketika pembaca telah melampaui pembacaan retroaktif atau hermeneutik.

(3) Matriks, Model, dan Varian

Secara teoretis puisi merupakan perkembangan dari matriks menjadi model dan ditransformasikan menjadi varian-varian. Dalam menganalisis karya sastra (puisi) matriks diabstraksikan berupa satu kata, gabungan kata, bagian kalimat atau kalimat sederhana (Salam, 2009:7). Matriks, model, dan varian-varian dikenali pada pembacaan tahap kedua.

Matriks bersifat hipotesis dan di dalam struktur teks hanya terlihat sebagai aktualisasi kata-kata. Matriks bisa saja berupa sebuah kata dan dalam hal ini tidak pernah muncul di dalam teks. Matriks selalu diaktualisasikan dalam varian-varian. Bentuk varian-varian tersebut diatur aktualisasi primer atau pertama, yang disebut sebagai model. Matriks, model, dan teks merupakan varian-varian dari struktur yang sama. Kompleksitas teks pada dasarnya tidak lebih sebagai pengembangan matriks. Dengan demikian, matriks merupakan motor atau generator sebuah teks, sedangkan model menentukan tata cara pemerolehannya atau pengembangannya.

(4) Hipogram: Hubungan Intertekstual

Untuk memberikan apresiasi atau pemaknaan yang penuh pada karya sastra, maka sebaiknya karya sastra tersebut disejajarkan dengan karya sastra lain yang menjadi hipogram atau latar belakang penciptaannya (Bernard dalam Salam, 2009:7). Pada dasarnya, sebuah karya sastra merupakan respon terhadap karya sastra yang lain. Respon itu dapat berupa perlawanan atau penerusan tradisi dari karya sastra sebelumnya. Hipogram merupakan latar penciptaan karya sastra yang dapat berupa keadaan masyarakat, peristiwa dalam sejarah, atau alam dan kehidupan yang dialami sastrawan.

Dengan demikian, objek formal dari analisis puisi dengan kerangka teori Riffaterre adalah "arti" (significance). Karena "arti" itu berpusat pada matriks atau hipogram yang tidak diucapkan di dalam puisinya sendiri, walaupun dapat disiratkannya, maka data mengenainya tidak dapat ditemukan di dalam teks, melainkan di dalam pikiran "pembaca" ataupun "pengarang" (Faruk, 2012:147).

Menurut Riffaterre, "arti” itu dapat ditemukan melalui berbagai bentuk objektivitasnya yang berupa teks. Namun, teks yang menjadi matriks atau hipogram itu sendiri baru bisa ditemukan setelah menemukan "makna" kebahasaan dari puisi yang bersangkutan. "Makna" kebahasaan itu adalah makna referensial yang berupa rangkaian ketidakgramatikalan (ungramatically), yaitu ketidaksesuaian antara satuan-satuan tanda kebahasaan yang ada di dalam teks dengan gambaran mengenai kenyataan yang diacunya. Karena "makna" ini bersifat kebahasaan, maka ia dapat ditemukan di dalam teks puisi yang diteliti atau dibaca. Hanya saja satuan-satuan makna kebahasaan itu sendiri belum memadai untuk membawa pembaca pada pengetahuan mengenai "arti" melainkan hanya menjadi "pengantar" ke arahnya. Satuan-satuan makna kebahasaan itu, yang berupa serangkaian ketidakgramatikalan tersebut, harus dihubungkan satu sama lain secara oposisional sehingga membentuk pasangan-pasangan oposisi yang saling ekuivalen dan bersifat paradigmatik. Untuk membentuknya menjadi pasangan-pasangan oposisional yang paradigmatik tersebut, pembaca harus melakukan pembacaan secara hermeneutik dan 
pembacaan dengan bantuan "konvensi sastra". Konvensi sastra berfungsi untuk menemukan kemungkinan-kemungkinan makna simbolik yang dapat mempertemukan satuan-satuan makna kebahasaan yang satu dengan yang lain, untuk melampaui secara bertahap serangkaian ketidakgramatikalan yang ada (Faruk, 2012:148).

2.2 Struktur lahir Puisi "Hujan Bulan Juni”

Hujan Bulan Juni

tak ada yang lebih tabah

dari hujan bulan juni

dirahasiakannya rintik rindunya

kepada pohon berbunga itu

tak ada yang lebih bijak

dari hujan bulan juni

dihapusnya jejak-jejak kakinya

yang ragu-ragu di jalan itu

tak ada yang lebih arif

dari hujan bulan juni

dibiarkannya yang tak terucapkan

diserap akar pohon bunga itu

1989

2.2. 1 Analisis Struktur Lahir Puisi Hujan Bulan Juni

1. Diksi

Diksi yang terdapat pada puisi Hujan Bulan Juni ini menggunakan diksi konotatif, karena didominasi oleh kata-kata yang tidak menggunakan makna sebenarnya. Terdapat dalam kutipan berikut ini.

"tak ada yang lebih tabah

dari hujan bulan juni" (bait ke-1)

tak ada yang lebih bijak

dari hujan bulan juni( bait ke-2)

\section{Gaya Bahasa}

Puisi ini diperkuat dengan majas personifikasi yang mewarnai seluruh puisi. Sungguh ungkapan rasa dan nuansa yang sangat romantis. Hal ini dapat terlihat pada kata hujan yang seolah-olah memiliki rasa seperti manusia yaitu rindu, bijak, arif, tabah, dan perilakunya (dirahasiakannya, dihapusnya, dibiarkan).

3. Bunyi

Rima: Bebas

Penyair membebaskan diri dalam rima tiap-tiap barisnya.

4. Tipografi

Tipografi pada puisi ini terdiri dari tiga bait dan tiap bait terdiri atas empat baris. Dalam puisinya sendiri ditulis dengan menggunakan rata kiri.

Analisis Struktur Batin Puisi Hujan Bulan Juni

1. Tema

$$
\text { Penantian }
$$

2. Nada dan Suasana

3. Perasaan

Romantik, menggambarkan suasana harmonis.

Memunculkan rasa tabah, bijak, dan arif.

4. Amanat/Itikad

Tidak ada yang tidak mungkin jika kita ingin berusaha. Sesungguhnya kekuatan cinta itu nyata.

5. Relevansi dengan kehidupan

Menggambarkan bahwa dalam mengharapkan sesuatu di hidup ini tidak selalu mudah didapat. Perlu adanya usaha yang sungguh-sungguh. Jika kita mau berusaha pasti akan ada hasil yang baik. 
Analisis puisi Hujan Bulan Juni dilakukan tiap-tiap kalimat karena tanda-tanda yang terdapat dalam puisi ini berbentuk kalimat, bisa dikatakan bukan merupakan satu kata saja. Maka analisisnya menurut kalimat-kalimat berikut ini.

1. Hujan Bulan Juni

2. Tak ada yang lebih tabah dari hujan bulan Juni

3. Dirahasiakannya rintik rindunya kepada pohon berbunga itu

4. Tak ada yang lebih bijak dari hujan bulan juni

5. Dihapusnya jejak-jejak kakinya yang ragu-ragu di jalan itu

6. Tak ada yang lebih arif dari hujan bulan juni

7. Dibiarkannya yang tak terucapkan diserap akar pohon bunga itu

\subsubsection{Pembacaan heuristik puisi Hujan Bulan Juni.}

1. Hujan bulan juni.

Dari judul puisi ini sendiri Hujan Bulan Juni memiliki arti hujan yang terjadi di bulan Juni.

2. Tak ada yang lebih tabah dari hujan bulan Juni.

Dalam KBBI kata tabah memiliki arti tetap dan kuat hati. Jadi kalimat ini mengartikan bahwa hujan di bulan juni memiliki sifat yang tetap dan kuat hati. Tidak ada yang melebihi ketabahan hujan di bulan Juni.

3. Dirahasiakannya rintik rindunya kepada pohon berbunga itu.

Dalam KBBI kata rahasia memiliki arti sesuatu yg sengaja disembunyikan supaya tidak diketahui orang lain. Kalimat ini mengartikan bahwa hujan di bulan juni menyembunyikan rindunya kepada pohon yang berbunga.

4. Tak ada yang lebih bijak dari hujan bulan juni.

Dalam KBBI kata bijak adalah selalu menggunakan akal budinya; pandai; mahir. Dalam kalimat ini mengartikan hujan di bulan juni menggunakan akal budinya, pandai dan mahir. Tidak ada yang lebih bijak dari hujan di bulan juni.

5. Dihapuskannya jejak-jejak kakinya yang ragu-ragu di jalan itu.

Dalam KBBI kata hapus adalah tidak terdapat atau tidak terlihat lagi; hilang. Kalimat ini berarti, hujan di bulan juni menghapus atau menghilangkan jejak-jejak kakinya yang ragu ragu.

6. Tak ada yang lebih arif dari hujan bulan juni.

Dalam KBBI kata arif adalah bijaksana; cerdik dan pandai; berilmu. Kalimat ini berarti, hujan bulan juni itu bijaksana, cerdik, berilmu dan pandai. Dan tak ada yang lebih arif dari hujan bulan juni.

7. Dibiarkannya tak terucapkan diserap akar pohon bunga itu.

Kalimat ini menerangkan bahwa hujan bulan juni membiarkan tak mengucapkan apa-apa air-air hujannya di serap oleh akar pohon yang berbunga.

\subsubsection{Pembacaan hermeneutik puisi Hujan Bulan Juni.}

Kita dapat memaknai puisi Hujan Bulan Juni ini dengan melihat judul yang dibuat oleh penyairnya, yaitu Hujan Bulan Juni. Seperti yang telah kita ketahui bahwa bulan juni merupakan musim kemarau yang jarang sekali hujan datang. Jadi hujan bulan juni dapat disimbolkan sebagai penantian. Dalam puisi ini menggambarkan seseorang yang tengah menanti seseorang yang ia kasihi. Untuk memaknai puisi Hujan Bulan Juni secara kesuluruhan dapat dilihat pembacaan hermeneutik dari setiap baitnya.

Bait pertama

Bait pertama menggambarkan seseorang yang dengan tabahnya menanti seseorang yang ia cintai. Ia memuji penantianya tidak ada yang lebih tabah dari penantiannya. Di bait pertama ini juga menggambarkan bahwa ia menyembunyikan rasa rindunya kepada seseorang yang indah yang ia cintai. Pohon berbunga itu diartikan sebagai seseorang yang indah yang dinanti.

Bait kedua

Bait ini menggambarkan penantian seseorang tersebut sangat bijak dan tak ada yang melebihi kebijakan penantiannya. Ia pun menghapus segala keraguannya dalam menanti dan mencintai seseorang tersebut.

Bait ketiga

Bait ketiga menggambarkan pemujian kembali terhadap penantiannya. Ia mengatakan kembali bahwa tidak ada yang lebih arif dari panantiannya. Di bait ketiga pula digambarkan bahwa pada akhirnya penantiannya berbuah hasil manis. Cintanya diterima oleh seseorang yang ia cintainya dapat dilihat dari kalimat diserap akar pohon bunga itu. Dan ia membiarkan tidak terucap segala apa yang ia rasakan selama penantian.

Simpulan

Puisi Hujan Bulan Juni karya Sapardi Djoko Damono menggambarkan tentang penantian seseorang kepada seseorang yang dinantinya. Dengan sangat tabah, bijak, dan arif ia menanti. Dengan merahasiakan segala rindunya, menghapus segala keraguannya dalam menanti. Akhirnya penantiannya 
berbuah manis. Ia mendapatkan seseorang yang dinantinya tersebut. Karena begitu tulusnya perasaan seseorang tersebut ia membiarkan tak terucapkan segala apa yang ia rasa selama menanti. Puisi ini sangat memberikan kita pelajaran betapa tidak ada yang tidak mungkin jika kita ingin berusaha. Sesungguhnya kekuatan cinta itu nyata.

2.3 Pengkajian Puisi Percakapan Senja

Percakapan Senja

Gde Artawan

Bagaimana harus kukatakan padamu

Saat kau menyodorkan luka sejarah di atas piring senja

Dengan tubuh yang luka dan wajah pecah di cermin

Matamu sebuah bola lampu pijar setengah padam

Sisa bayangan danau kering di rimba tak terjamah

Ketika kedua tanganmu menjulur

Di telapaknya tak kutemukan

Guratan mawar

Dan kelebatan burung-burung pantai

Aku tak lagi bisa berkaca di tubuhmu

Karena tubuhku luka pesisir

Tubuhmu luka pegunungan

Menjadi bagian luka sejarah

Bertebaran merata di pasir,

di setiap ceruk

di kedalaman hati

\subsubsection{Analisis Struktur Lahir Puisi Percakapan Senja}

1. Diksi

Diksi yang terdapat pada puisi Percakapan Senja ini menggunakan diksi konotatif, karena didominasi oleh kata-kata yang tidak menggunakan makna sebenarnya. Terdapat dalam kutipan berikut ini.

Aku tak lagi bisa berkaca di tubuhmu

Karena tubuhku luka pesisir

Tubuhmu luka pegunungan

(bait ke-3)

2. Gaya Bahasa

Puisi ini diperkuat dengan majas metafora dan personifikasi. Hal ini dapat terlihat pada kalimat Matamu sebuah bola lampu pijar setengah padam. Sebuah perbandingan tatapan mata dengan bola lampu pijar yang hampir padam, yang melukiskan nuansa kehidupan yang mulai redup, semangat hidup yang mulai berkurang.

Selain baris bola mata, tampak pula metafora pada baris - baris dalam bait ke-3

Aku tak lagi bisa berkaca di tubuhmu

Karena tubuhku luka pesisir

Tubuhmu luka pegunungan

Tubuhmu seolah-olah cermin, lalu luka tubuh diibaratkan dengan luka pesisir dan luka pegunungan.

3. Bunyi

Rima: Bebas

4. Tipografi

Tipografi pada puisi ini terdiri dari dua bait. Bait pertama berisi sembilan baris, dan bait kedua berisi tujuh baris. Puisi ini ditulis dengan perwajahan bentuk variasi. Diawali dengan rata kiri pada bait pertama, diakhiri dengan baris yang menjorok ke tengah.

2.3.2 Analisis Struktur Batin Puisi Percakapan Senja

1. Tema

Perpisahan

2. Nada dan Suasana

, menggambarkan suasana batin yang berduka/ sedih

3. Perasaan

"Sentimentil" yakni sebuah rasa, perasaan penuh haru, rawan, lembut hati, dan terlalu berlebihlebihan. Sehingga memunculkan rasa iba terhadap suasana komunikasi yang sudah kurang harmonis 4. Amanat/Itikad 
Suatu ikatan " penyatuan sesuatu”, apalagi sesuatu bernyawa dan berperasaan hendaknya dilandasi dan dilatarbelakangi "kesamaan" visi, misi, wawasan. Jikalau tidak demikian, yang lebih penting adalah kesiapan dan keikhlasan untuk "menyatukan diri" ke dalam "ikatan" yang sudah dijalin.

5. Relevansi dengan kehidupan

Menggambarkan kondisi yang menyatakan bahwa tidaklah mudah untuk menyatukan batin dalam sebuah ikatan yang "kokoh", karena setiap individu pasti memiliki latar belakang yang tidak sama, bahkan bisa jadi bertolak belakang.

Meski sama- sama memiliki unsur kesamaan, namun karena kesamaan dimaksud bersumber dari asal-usul yang berbeda, maka ketika tidak ada kerendahan hati dan kelegaan hati untuk melarutkan diri (karena dibelenggu oleh ego masing- masing). Hal ini tercermin pada kata "luka" dalam puisi Percakapan Senja.

Analisis puisi Percakapan Senja dilakukan tiap-tiap kalimat karena tanda-tanda yang terdapat dalam puisi ini berbentuk kalimat, bisa dikatakan bukan merupakan satu kata saja. Maka analisisnya menurut kalimat-kalimat berikut ini.

1. Percakapan Senja

2. Bagaimana harus kukatakan padamu

3. Saat kau menyodorkan luka sejarah di atas piring senja

4. Dengan tubuh yang luka dan wajah pecah di cermin

5. Matamu sebuah bola lampu pijar setengah padam

6. Sisa bayangan danau kering di rimba tak terjamah

7. Ketika kedua tanganmu menjulur

8. Di telapaknya tak kutemukan

9. Guratan mawar

10. Dan kelebatan burung-burung pantai

11. Aku tak lagi bisa berkaca di tubuhmu

12. Karena tubuhku luka pesisir

13. Tubuhmu luka pegunungan

14. Menjadi bagian luka sejarah

15. Bertebaran merata di pasir,

16. di setiap ceruk

17. di kedalaman hati

\subsubsection{Pembacaan heuristik puisi Percakapan Senja.}

1. Percakapan Senja

Dari judul puisi Percakapan Senja ini sendiri memiliki arti percakapan yang terjadi di pada senja hari. (makna denotasi senja berarti akan berakhirnya siang, konotasinya akan berakhirnya suatu hubungan)

2. Bagaimana harus kukatakan padamu

3. Saat kau menyodorkan luka sejarah di atas piring senja

Dalam KBBI kata luka memiliki arti belah ( pecah, cidera, lecet, dsb) KBBI, 2005:687). Jadi kalimat ini mengartikan bahwa percakapan Senja merupakan dialog yang terputus, karena terkendala oleh luka, pecah, atau cideranya komunikasi.

4. Dengan tubuh yang luka dan wajah pecah di cermin

Dalam KBBI kata pecah memiliki arti sesuatu yang terbelah menjadi beberapa bagian (KBBI, 2005:839) . Kalimat ini mengartikan bahwa percakapan senja sangat tidak komunikatif karena di samping disodori luka yang berarti pecah, cidera, diperkuat dengan kata luka di tubuh dan wajah yang pecah di cermin, 5. Matamu sebuah bola lampu pijar setengah padam

Dalam KBBI kata padam berarti mati (tt api); tidak menyala atau tidak berkobar lagi (KBBI on line) 4 menjadi lemah (tt semangat).

Dalam kalimat ini menggambarkan redupnya semangat seseorang yang tercermin dari tatapan mata.

6. Sisa bayangan danau kering di rimba tak terjamah

Menurut KBBI on line sisa /si·sa/ $n$ apa yg tertinggal (sesudah dimakan, diambil, dsb) danau 1 /da·nau / $n$ genangan air yg amat luas, dikelilingi daratan; telaga; tasik; rimba /rim·ba/ $n$ hutan lebat (yg luas dng pohon yg besar-besar): hilang tidak tentu -- nya, hilang lenyap tanpa meninggalkan kesan atau jejak;

Kalimat sisa bayangan danau kering di rimba tak terjamah memberikan arti sesuatu yang tak ada. Atau hanya ada dalam sebuah angan- angan. Karena bayangan akan ada jika sesuatu dipantulkan melalui 
air (dalam hal ini air danau). Namun danau itu telah kering, dilanjutkan dengan kata di rimba tak terjamah. Kata rimba adalah hutan lebat dengan pohon yang besar, terjamah dalam KBBI 1 sudah dijamah; 2 dijamah tanpa disengaja; tersentuh; 3 dimasuki; dikenal (tt daerah, hutan). Tak terjamah, berarti tak dikenal, sangat tersembunyi.

7. Ketika kedua tanganmu menjulur

8. Di telapaknya tak kutemukan

9. Guratan mawar

Kata menjulur dalam KBBI keluar memanjang (spt lidah ular, cecak). Gurat berarrti gores (garis, coret) yg dalam. Mawar dalam KBBI on line bunganya beraneka warna, spt merah, putih, merah jambu, merah tua, berbau harum; 2 bunga mawar; bunga ros; (melambangkan keindahan dan kesenangan, pen).

Tiga kalimat dalam puisi di atas, secara harfiah berdasarkan arti dalam kamus memberikan gambaran tidak ditemukannya goresan atau bekas kebahagiaan maupun kesenangan yang kuat dalam diri seseorang yang diajak berdialog.

10. Dan kelebatan burung-burung pantai

Kelebatan dalam KBBI on line berkelebatan /ber·ke·le·bat·an/ $v$ bergerak dng cepat; mengadakan gerakan cepat; artinya keceriaan atau kedinamikaan hidup, tak ditemukan lagi oleh seseorang yang sedang diajak berdialog.

11. Aku tak lagi bisa berkaca di tubuhmu

12. Karena tubuhku luka pesisir

13. Tubuhmu luka pegunungan

Kalimat nomor (11) s.d (13) merupakan satu rangkaian. Jika dilihat dari arti kata menurut KBBI, berkaca berkaca /ber $\cdot \mathrm{ka} \cdot \mathrm{ca} / v 1$ memakai kaca: jendelanya tidak $; 2$ becermin: berkali-kali ia untuk membetulkan sanggulnya; $3 \mathrm{ki}$ mengambil sbg contoh teladan: ia selalu $\sim \mathrm{kpd}$ pengalamannya;

Kata pesisir menurut KBBI pesisir /pe-si·sir/ $n$ tanah datar berpasir di pantai (di tepi laut); Sedangkan pegunungan berasal ari kata gunung yang berarti gunung /gu·nung/ $n$ bukit yg sangat besar dan tinggi (biasanya tingginya lebih dr $600 \mathrm{~m}$ );-- juga yg dilejang panas, pb 1 biasanya orang yg sudah kaya yg mendapat untung atau bertambah kaya;

Rangkaian ketiga kalimat di atas secara kamus dapat diartikan bahwa seseorang sudah tidak bisa lagi bercermin ( atau meneladani) atau saling mengingatkan (pen) karena keduanya ( dua orang) yang berada dalam dialog tersebut bertolak belakang (yang satu memiliki "luka" pesisir dan yang lainnya memiliki "luka" pegunungan)

14. Menjadi bagian luka sejarah

15. Bertebaran merata di pasir,

16. di setiap ceruk

17. di kedalaman hati

Kalimat no. (14) s.d (17) merupakan ending dari kisah. Biarlah menjadi bagian dari kisah sejarah yang "menyedihkan" dan merata di relung-relung kehidupan.

\subsubsection{Pembacaan hermeneutik puisi Percakapan Senja.}

Kita dapat memaknai puisi Percakapan Senja ini dengan melihat judul yang dibuat oleh penyairnya, yaitu Percakapan Senja. Seperti yang telah kita ketahui bahwa senja merupakan penghujung hari atau akhir siang hari menjelang malam, yang merupakan akhir dari aktivitas "kerja". Jadi percakapan senja ini dapat disimbolkan sebagai komunikasi menjelang berakhirnya sebuah "kesepakatan bersama". Dalam puisi ini digambarkan seseorang yang tengah berdialog dengan seseorang yang selama ini menemaninya atau mendampinginya. Untuk memaknai puisi Percakapan Senja secara kesuluruhan dapat dilihat pembacaan hermeneutik dari setiap baitnya.

Bait pertama

Bait pertama menggambarkan seseorang yang sedang mengajak berdialog dengan seseorang yang ia "cintai". Namun ia tak lagi menemukan sesuatu yang dulu pernah ia jumpai pada seseorang dimaksud. Betapa ia ingin berkomunikasi dengan baik, namun ketika seseorang yang diajak bicara tibatiba memunculkan ekspresi "luka" dengan segala kesedihannya sampai- sampai tidak menyisakan bekasbekas kebahagiaan maupun keceriaan yang pernah terjadi selama ini.

Bait kedua

Bait ini menggambarkan keputusan dari seseorang, setelah mengalami apa yang dilukiskan pada bait pertama. Ia menyimpulkan diantara kedua orang tersebut memang merupakan dua sosok yang memiliki kesamaan. Namun kesamaan " luka" yang bertolak belakang, dan tak mungkin lagi dipersatukan.Dan pada akhirnya membiarkan kisah mereka menjadi sebuah episode dalam sejarah . Simpulan 
Puisi Percakapan Senja karya Gde Artawan menggambarkan tentang akhir dari sebuah kebersamaan yang menemui titik kebuntuan dalam "berkomunikasi" yang dilatarbelakangi perbedaan yang sangat kuat dan ketiadaan kemauan yang kuat pula untuk saling meleburkan diri menjadi sebuah ikatan yang kuat. Sehingga pada akhirnya membiarkan masing- masing berjalan sesuai dengan jalurnya.

\section{Simpulan}

Dari pembahasan di atas dapatlah disimpulkan bahwa:

1) Analisis Puisi Hujan Bulan Juni

Puisi Hujan Bulan Juni karya Sapardi Djoko Damono menggambarkan tentang penantian seseorang kepada seseorang yang dinantinya. Dengan sangat tabah, bijak, dan arif ia menanti. Dengan merahasiakan segala rindunya, menghapus segala keraguannya dalam menanti. Akhirnya penantiannya berbuah manis. Ia mendapatkan seseorang yang dinantinya tersebut. Karena begitu tulusnya perasaan seseorang tersebut ia membiarkan tak terucapkan segala apa yang ia rasa selama menanti. Puisi ini sangat memberikan kita pelajaran betapa tidak ada yang tidak mungkin jika kita ingin berusaha. Sesungguhnya kekuatan cinta itu nyata.

2) Analisis Puisi "Percakapan Senja”

Puisi Percakapan Senja karya Gde Artawan menggambarkan tentang akhir dari sebuah kebersamaan yang menemui titik kebuntuan dalam "berkomunikasi" yang dilatarbelakangi perbedaan yang sangat kuat dan ketiadaan kemauan yang kuat pula untuk saling meleburkan diri menjadi sebuah ikatan yang kuat. Sehingga pada akhirnya membiarkan masing- masing berjalan sesuai dengan jalurnya.

\section{Referencsi}

Djoko Damono, Sapardi 2013. Hujan Bulan Juni 1959-1994, Sepilihan Sajak . Jakarta, Gramedia Pradopo, D.R. 2005. Beberapa Teori Sastra, Metode Kritik, dan Penerpannya. Yogyakarta: Pustaka Pelajar. Pradopo, D. R. 2010. Pengkajian Puisi. Yogyakarta: Gadjah Mada University Press.

Junus, U. 1988. Karya Sebagai Sumber Makna: Pengantar Strukturalisme. Kuala Lumpur: Dewan Bahasa dan Pustaka.

Sely Desilia, Menikmati Penantian, http://desiliasely.blogspot.com/2014/01/kajian-puisi-hujan-bulanjuni-semiotik.html diunduh tanggal 27 Jan 2015

Faruk. 2012. Metode Penelitian Sastra, Sebuah Penjelajahan Awal. Yogyakarta:

Pustaka Pelajar.

Gde Artawan, 2014. Tubuhku Luka Pesisir, Tubuhmu Luka Pegunungan. Singaraja Mahima,

KBBI on line diunduh tanggal 2 Februari 2015

Salam. 2009. "Pembelajaran Menulis Puisi Dengan Metode Michael Riffaterre"

https://bambangsantoso.wordpress.com/2012/12/03/mengenal-semiotika-michael-riffaterre/

diunduh tanggal 2 Februari 2015 